\title{
Investigation of Antireflective Porous Silicon Coating for Solar Cells
}

\author{
Hyukyong Kwon, Jaedoo Lee, Minjeong Kim, and Soohong Lee \\ Department of Electronics Engineering, Sejong University, 98 Gunja-Dong, Gwangiin-Gu, Seoul 143-747, Republic of Korea \\ Correspondence should be addressed to Soohong Lee, shl@sejong.ac.kr
}

Received 22 March 2011; Accepted 19 April 2011

Academic Editor: D. K. Sarker

Copyright () 2011 Hyukyong Kwon et al. This is an open access article distributed under the Creative Commons Attribution License, which permits unrestricted use, distribution, and reproduction in any medium, provided the original work is properly cited.

Solar cell is device that directly converts the energy of solar radiation to electrical energy. So it is important for solar cell to reduce the surface reflection of light in order to improve the efficiency of the device. Texturing and antireflection coating have been used to reduce the reflection of light. Texturing technology has reduced the $10 \%$ of incident light. However, there are a few disadvantages of random pyramid texturing that the results are not always reproducible in an industrial environment. And $\mathrm{AR}$ coating $\left(\mathrm{MgF}_{2}\right.$, $\mathrm{ZnS}$ ) is difficult to apply the standard industrial process because high vacuum is needed and the expense is very heavy. This paper investigates the formation of a thin film of porous silicon on the surface of crystalline silicon substrate without other AR coating layers. The formation of the porous silicon layer was measured with SEM (scanning electron microscopy). The formation of porous silicon layers on the textured silicon wafer resulted in lower than $5 \%$ of reflectance in the wavelength region from 400 to $1000 \mathrm{~nm}$.

\section{Introduction}

It is one of the most important issues to reduce optical losses in crystalline silicon solar cells by surface modification. Porous silicon as a new material was first reported over 40 years ago by Uhlir. It is well known that a porous silicon (PS) layer formed in the $\mathrm{n}^{+}$, emitter of a Si solar cell can be used as an effective antireflection coating. The visible light emission from PS has generated a great deal of interest due to its potential technological applications. It is widely believed that PS can be adapted to mass production of solar cells because of the simple and cheap technology.

The PS is produced by anodisation of Si wafers in a solution of hydrofluoric acid (HF) with current densities below those used for electropolishing. This imposes that the PS formation does not cause any damage to the electrical contacts. The PS formation mechanism in chemical etching depending on solution concentration, temperature, and etching time is a more simple process than the electrochemical one. The porosity was controlled by gravimetrical methods and calculated by equations

$$
P=\left(\frac{\left(m_{1}-m_{2}\right)}{\left(m_{1}-m_{3}\right)}\right) * 100 \%
$$

where $m_{1}$ is initial substrate weight, $m_{2}$ weight after anodisation, and $m_{3}$ weight after removing the PS layer in the $\mathrm{NaOH}$ mixture.

In this paper, porous Si layers on the front surface of textured Si substrates have been investigated with the aim of improving the optical losses of the solar cells because an ARC and a surface passivation can be obtained simultaneously in one process.

\section{Experiment}

The silicon samples used in this study were a resistivity in the range of $0.5-3.0 \Omega \mathrm{cm}<100>$ oriented $\mathrm{CZ}$ p-Si wafers. All samples had identical thickness of $200 \mu \mathrm{m}$ and size of $4 \mathrm{~cm}^{2}$. Prior to the phosphorous emitter diffusion, the wafers received a standard cleaning and additionally the samples were textured at $80 \sim 85^{\circ} \mathrm{C}$ for $30 \mathrm{~min}$ in a $\mathrm{KOH}(20 \%)$ texturing solution [1].

The textured wafers were diffused under optimized conditions using diffusion source of $\mathrm{POCl}_{3}$. The predeposition was carried out under the condition at $830^{\circ} \mathrm{C}$ for $20 \mathrm{~min}$, and the drive-in was carried out under the condition at $830^{\circ} \mathrm{C}$ for $15 \mathrm{~min}$. As a result, the sheet resistance of the $\mathrm{n}^{+}$ 


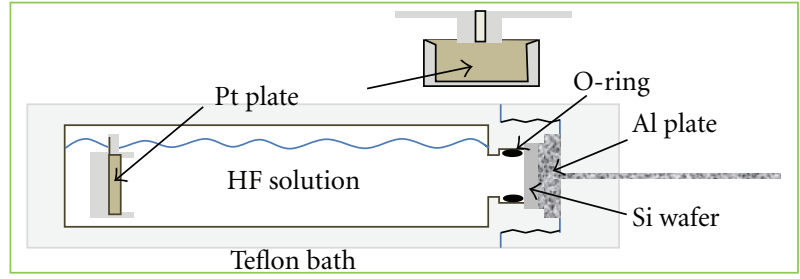

FIgURE 1: Schematic of a conventional single-tank cell.

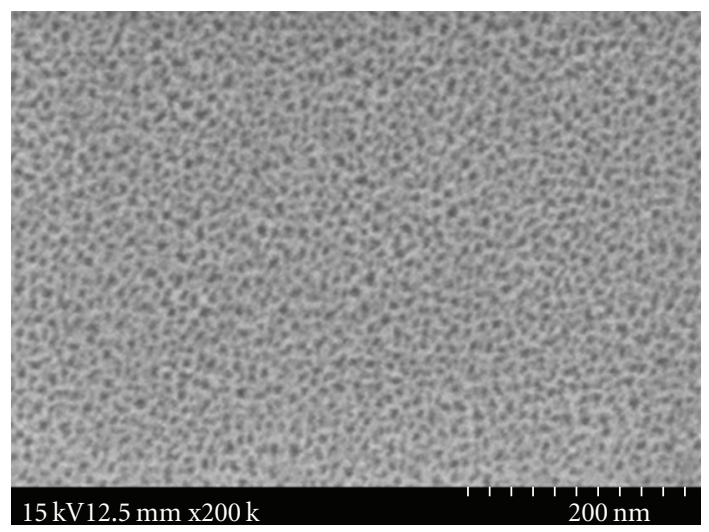

(a)
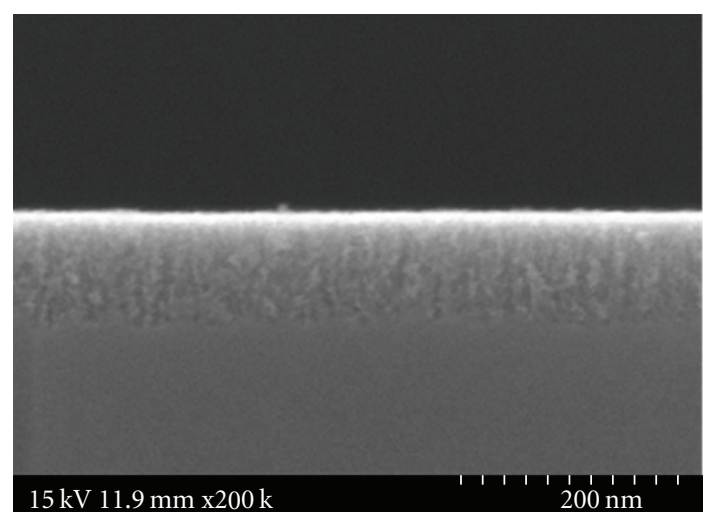

(b)

FIGURE 2: Formation of porous layer.

region was found to be less than $25 \Omega / \square$. The phosphosilicate glass layer was removed from the silicon surface with diluted hydrofluoric acid (HF). The electrical contacts were made by a screen printing process, with FERRO silver paste for front and aluminum paste for the back contacts. Metallization was done at $860^{\circ} \mathrm{C}$ for $2 \mathrm{~min}$ in the conventional annealing furnace. Lastly, the porous silicon layers were grown on the $\mathrm{n}^{+}$region by electrochemical etching process.

In this study, we did not make antireflection coatings. To measure I-V curve characteristics of solar cells, the PS layers were performed in a special Teflon bath using a two-electrode arrangement. Figure 1 is schematic of a conventional singletank cell.

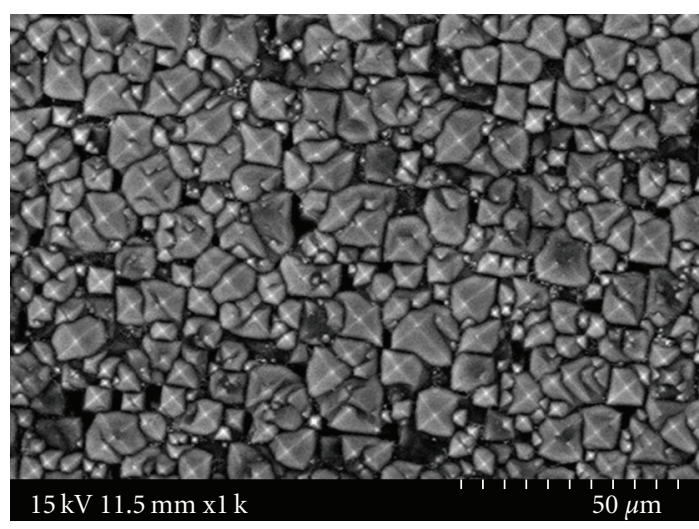

(a)

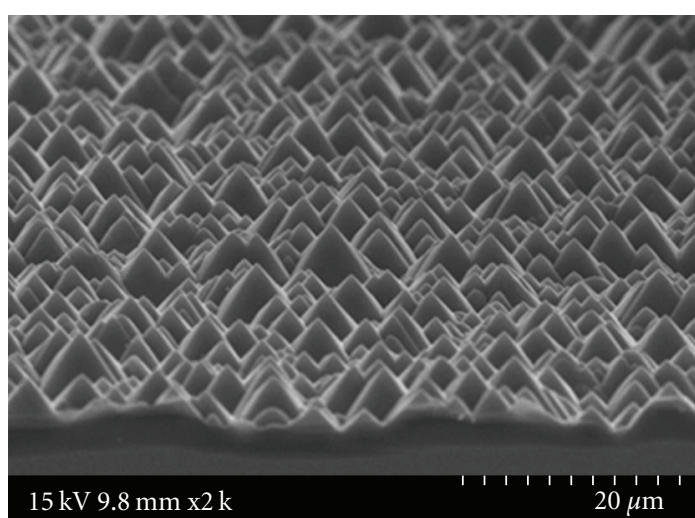

(b)

FIgURE 3: Formation of textured Si.

The anodisation was carried out with a current density of $20 \mathrm{~mA} / \mathrm{cm}^{2}$ applied during $10 \mathrm{sec}$. As a result, we obtained a blue-coloured silicon layer between the grid fingers on the surface $4 \mathrm{~cm}^{2}$ of the $\mathrm{n}^{+}$emitter silicon solar cells. The sheet resistivity of the porous layer measured by a 4-point method was close to about $100 \Omega / \square$.

\section{Result and Discussion}

The alkaline textured Si of the A sample in Figure 2, the PS layer formation of the B sample in Figure 3 and the PS layer formation after textured $\mathrm{Si}$ of the $\mathrm{C}$ sample in Figure 4 are plotted on reflectance characteristics in Figure 5.

It can be seen that the PS layer caused a decrease in reflectivity as did antireflection coating. The minimum reflectivity for a blue-colored PS layer is $600 \mathrm{~nm}$ which is optimum for a solar cell. In contrast with antireflection coating, the PS layer caused noticeable decrease in reflectivity for shot wavelengths below $400 \mathrm{~nm}$ in Figure 5 .

In the case of textured surfaces, the PS layer gives additional decrease of reflectivity $(400-1000 \mathrm{~nm})$ for a silicon solar cell. This demonstrates that PS could be used as antireflection coating in solar cells, bearing in mind that its preparation is much simpler to implement and it is less 
TABLE 1: The results from the three kinds of solar cells measured under an AM 1.5 global spectrum.

\begin{tabular}{lccc}
\hline & A sample & B sample & C sample \\
\hline Solar cell parameters & Si-Cz textured & Si-Cz PS layer formation & Si-Cz PS layer formation after texturing \\
Isc (A) & 0.13 & 0.15 & 0.16 \\
Voc (V) & 0.56 & 0.56 & 0.57 \\
FF $(\%)$ & 55.27 & 64.33 & 65.77 \\
Eff. $(\%)$ & 9.55 & 10.52 & 11.28 \\
\hline
\end{tabular}

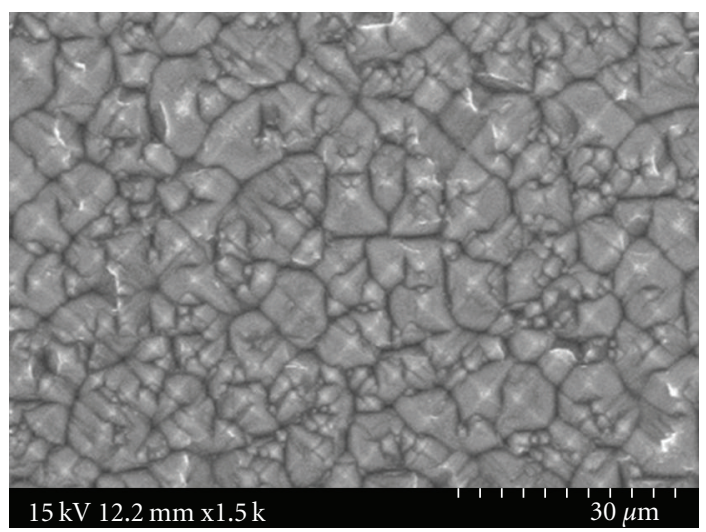

(a)

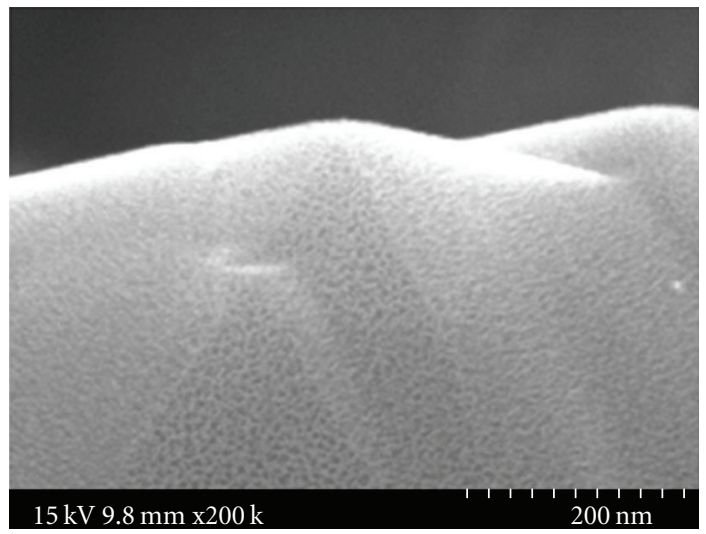

(b)

FIgURE 4: Formation of textured Si with porous layer.

expensive than multilayer antireflection coating which often requires deposition in vacuum. To obtain results compared with antireflection coatings like $\mathrm{MgF}_{2}, \mathrm{ZnS}$, the technology of a PS layer should be optimized.

The silicon solar cells performed as PS/ $\mathrm{n}^{+} / \mathrm{p}$-Si structure, shown in Figure 5, have been measured under AM 1.5 global spectrum, and the electrical parameters of $\mathrm{A}, \mathrm{B}$, and $\mathrm{C}$ samples are reported in Table 1.

The following effects can be observed on the basis of experimental results and the data listed in Table 1. Short circuit current of $\mathrm{Cz}-\mathrm{Si}$ PS layer formation after texturing gains more than $0.02 \mathrm{~A}$ for solar cell on the textured $\mathrm{Si}-\mathrm{Cz}$

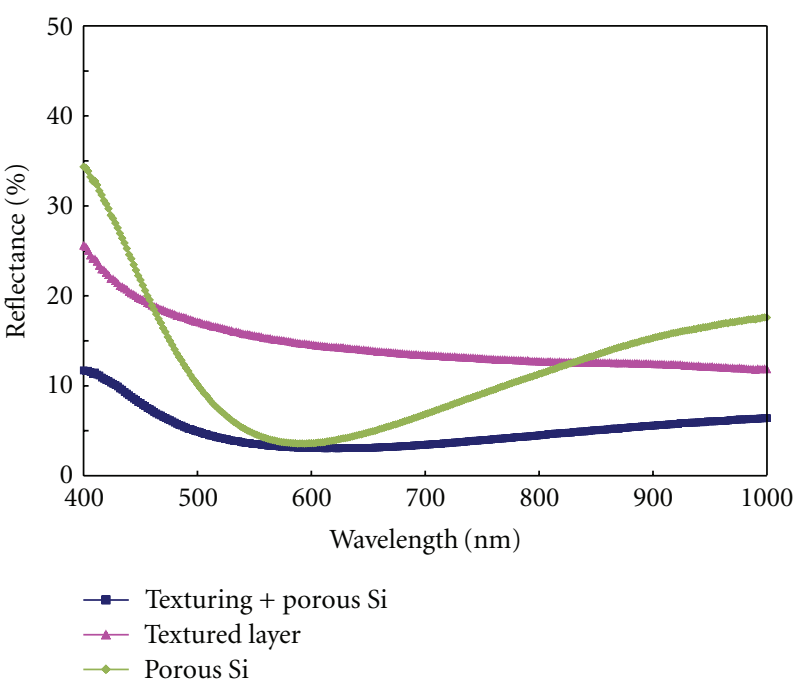

FIGURE 5: Surface reflectance of textured Si and reflectivity of forming porous layer and reflectivity of Textured Si with porous layer.

and more than $0.01 \mathrm{~A}$ for a solar cell on the PS layer formation.

Voc remains the same in solar cells with a porous layer as compared to the solar cells with textured $\mathrm{Si}$, demonstrating that PS does not introduce noticeable degradation in this respect and does not attack the metallic contacts and their adherence to the cell. The cell efficiency increases by about $2 \%$ for $\mathrm{Cz}$-Si PS layer formation after texturing more than textured Cz-Si for a solar cell (Figure 6).

The main conclusions can be extracted from these results: a porous surface layer might act as an antireflection coating that gives as a result an increase in short circuit current and efficiency of a solar cell. Additionally, the formation of the PS layer removes the highly doped dead layer between the fingers from the top surface of the emitter.

Due to this process, we can make the selective emitter and antireflection coating in one technological step. The very important fact is that the porous layers reported here have been homogeneous on a large surface of the silicon solar cells.

We think that it is a very simple and low-cost porous formation process that can be easily applied, in the future, in photovoltaic cell technology as a standard procedure. 


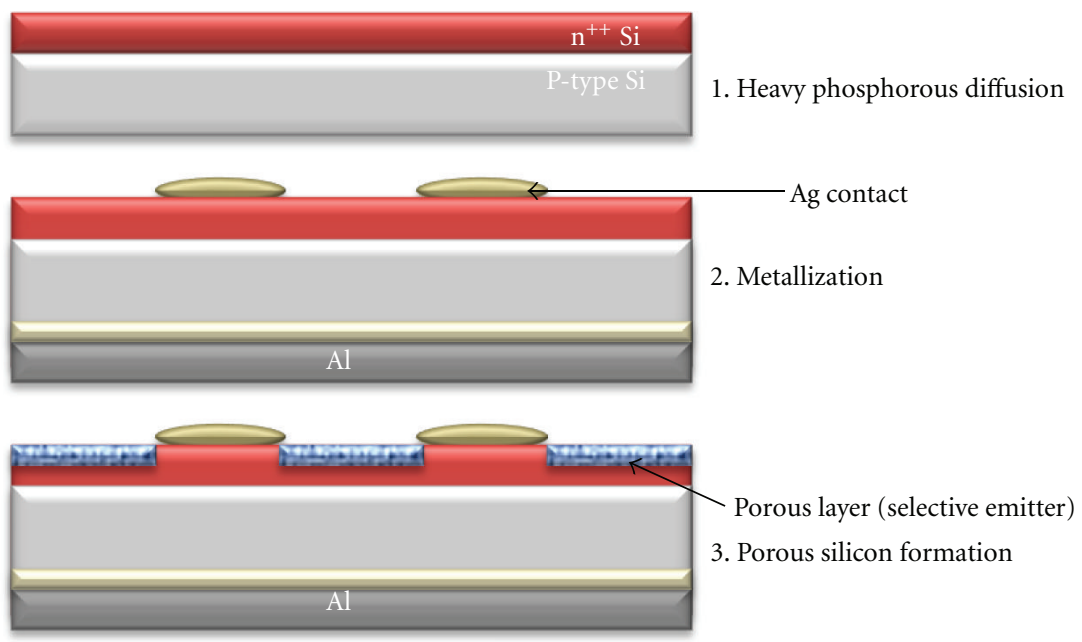

FIGURE 6: PS ARC formation by electrochemical etching on a Si solar cell with the electrical front and back contacts.

\section{Acknowledgment}

This work was supported by the Ministry of Knowledge Economy (MKE) on the human resources training project under Contract no. 20100493.

\section{References}

[1] D. L. King and M. E. Buck, "Experimental optimisation of an anisotropic etching process for random texturisation of silicon solar cells," in Proceedings of the 22nd IEEE Photovoltaic Specialists Conference(PVSPC'91), pp. 303-308, Las Vegas, Nev, USA, 1991. 

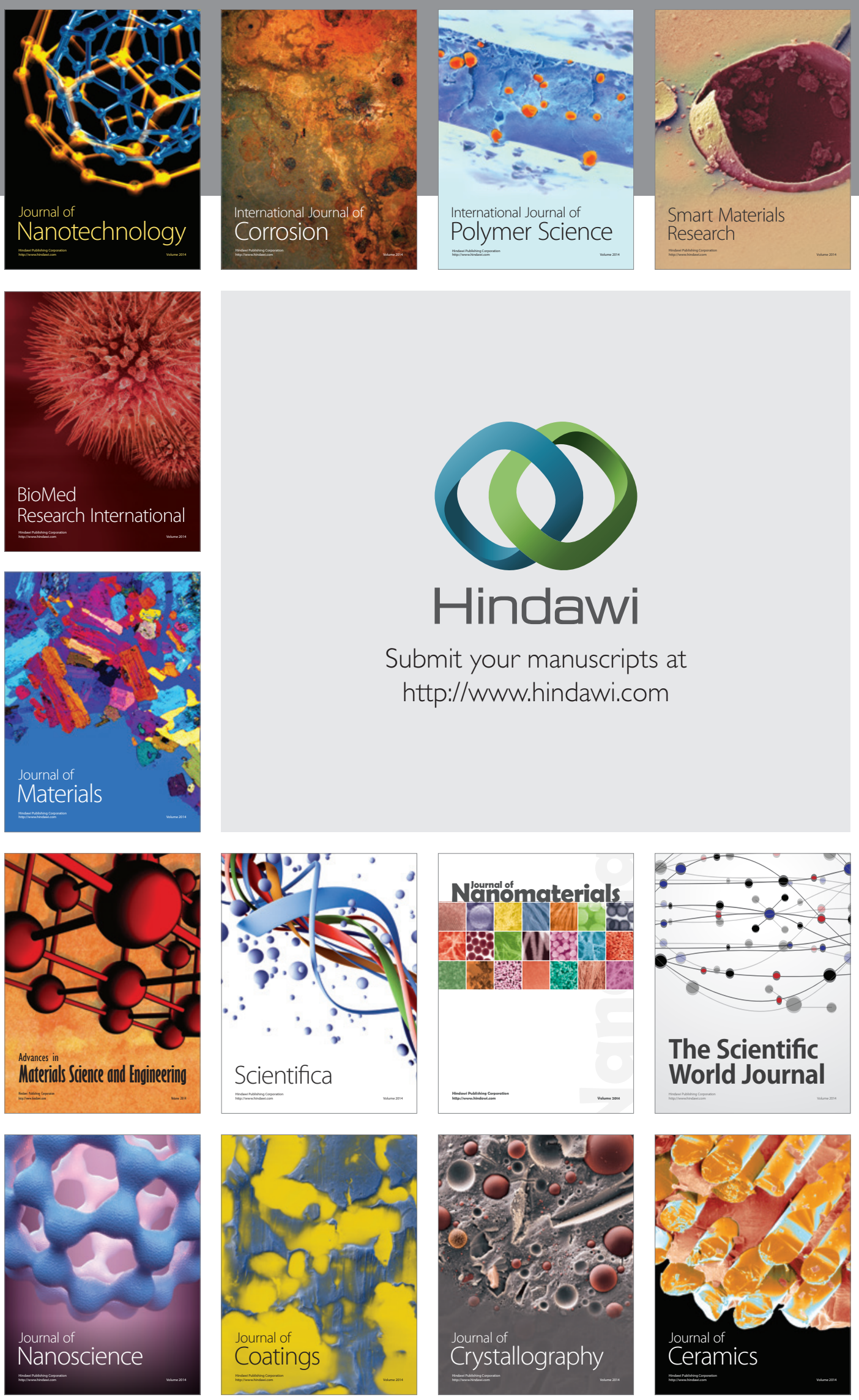

The Scientific World Journal

Submit your manuscripts at

http://www.hindawi.com

\section{World Journal}

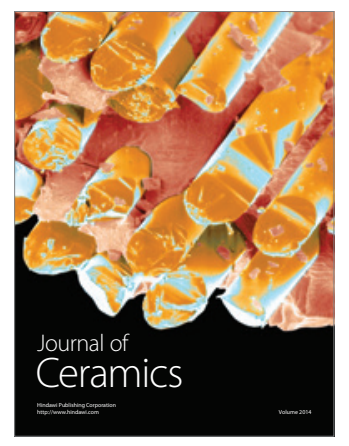

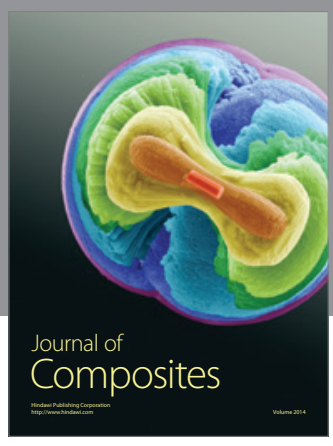
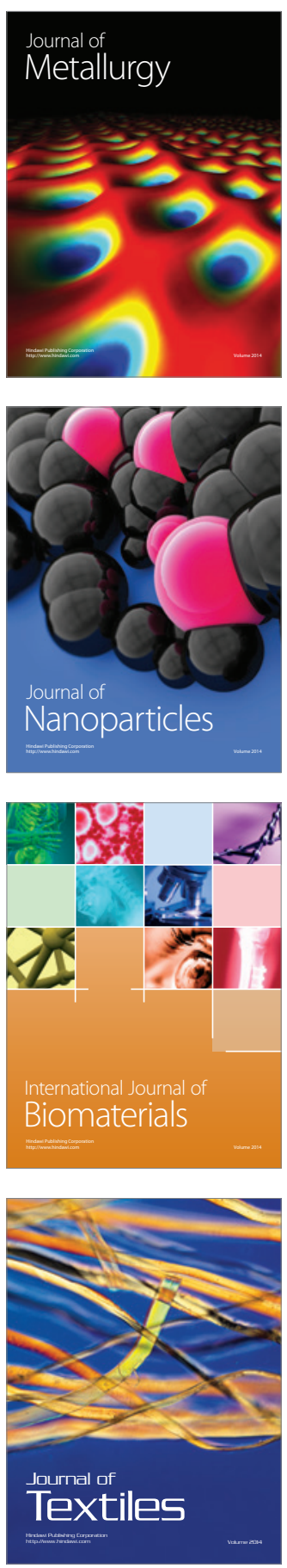